ISLLAC

Journal of Intensive Studies on Language, Literature, Art, and Culture

Vol. 1 No. 1 September 2017

\title{
TEACHING MATERIALS AND TECHNIQUES NEEDED BY FOREIGN STUDENTS IN LEARNING BAHASA INDONESIA
}

\author{
Imam Suyitno ${ }^{1}$, Gatut Susanto ${ }^{2}$, Musthofa $\mathrm{Kamal}^{3}$, Ary Fawzi ${ }^{4}$ \\ (imam.suyitno.fs@um.ac.id and gatutus@yahoo.com) \\ Universitas Negeri Malang (State University of Malang) Indonesia
}

\begin{abstract}
The study outlined in this article aimed to describe teaching materials and techniques needed by foreign students in learning Bahasa Indonesia. In learning BIPA, teaching materials and learning techniques are important aspects that need to be selected and organized seriously. The characteristics and objectives of BIPA learners are the main factors that need to be considered and understood by BIPA teachers. In this case, BIPA teachers must master the pedagogical norm of BIPA learning. Understanding of pedagogical norms will lead BIPA teachers to be able to determine the materials and learning techniques in accordance with the conditions of BIPA students.
\end{abstract}

Keywords: teaching materials, techniques, foreign students, Bahasa Indonesia

\section{INTRODUCTION}

Learning Bahasa Indonesia for foreign students (BIPA) is a potential vehicle for introducing and promoting an Indonesian society and culture to a foreigner. Therefore, BIPA learning program needs to be well designed. BIPA institutions have to manage and think seriously BIPA learning pedagogical norms that can guide in learning Bahasa Indonesia more professional. One of the pedagogical norms is the selection of teaching materials and the teaching techniques in presenting the teaching materials.

Pedagogical norms in the selection of teaching materials to be essential for BIPA teachers and materials developers in an effort to incorporate aspects of culture and language into the learning program and present it to the foreign students. The pedagogical norms involve the study of cultural norms and the actual use of the language and its implementation for pedagogical purposes. Such an activity is conducted from the design material that will be taught to the creation of classroom 
ISLLAC

Journal of Intensive Studies on Language, Literature, Art, and Culture

Vol. 1 No. 1 September 2017

learning activities from day to day (Bardovi-härlig and Gass, 2002). In applying the pedagogical norms to develop learning BIPA, teachers require an adequate understanding of the learning needs of students BIPA. Understanding of the characteristics of BIPA students is the starting point in preparing and implementing learning BIPA.

Generally, BIPA students are adults who have different cultural backgrounds with the culture of the language they learn. Thus, the characteristics of students have implications for the peculiarities of material selection and presentation in learning BIPA. Characteristics of the BIPA learning needs with differentiated learning Indonesian for Indonesian students in general. Wojowasito (1976:38) said that (1) the learning BIPA does not integrate into the student environment, (2) BIPA almost learned in adulthood or on when someone has mastered a number of first language structures, and (3) BIPA processed outside the system itself.

There are some aspects that must be considered in relation to learning BIPA. First, BIPA students already have quite a lot of knowledge and insight, so that their needs are also the need for an adult people. Second, foreigners like to express themselves, to present something, express their opinions, so that tasks outside the classroom will be very interesting. Third, to accommodate the interests and needs that may differ from one another, a variety of materials need to be prepared (Soegino, 1995:6).

Starting from the description above, in an effort to understand the pedagogical norms in line with the needs of foreign students studying in the following description, presented a discussion of (a) the characteristic of BIPA students, (b) student learning objectives BIPA, (c) the election materials pedagogical norms BIPA teaching, (d) BIPA variety of learning materials, (e) the development of teaching material culture, (f) BIPA learning approach, and (g) learning techniques BIPA. 
ISLLAC

Journal of Intensive Studies on Language, Literature, Art, and Culture

Vol. 1 No. 1 September 2017

\section{THE CHARACTERISTIC OF BIPA STUDENTS}

BIPA students are foreign students from various countries. Therefore, they have the language and cultural backgrounds are different from the language and culture of Indonesia. In addition, their knowledge and skills about the Indonesian language are varied. In fact, learning styles and strategies were highly variable and highly dependent on their respective cultures.

In teaching-learning BIPA, language and cultural differences have consequences on the selection of Indonesian material that will be taught. In the early stages of learning BIPA, foreign students are still heavily influenced by the first language, culture, and learning styles that they have learned. Mastery and acquisition of Indonesian of BIPA students are strongly influenced by the first language. Lee quoted by Ellis (1986:23) said that the only cause of difficulties and errors in learning a second language or a foreign language is the first language influence students. At this stage, which is controlled by the Indonesian foreign students is characterized by the presence of interference from the first language. However, this interference will gradually be reduced, which ultimately achieve mastery of Indonesian students similar to native speakers.

One of the problems in learning a foreign language is a gap between the first language and the target language to be learned. This often happens because of a lack of knowledge of the target language by foreign language learners. In general, it can be said that the length of the gap is the more difficult of the learning process, and the closer of the gap is the easier of the learning process. Grabe (1986) said that the problem of learning a foreign language emerged as a result of linguistic differences and sociocultural of the first language and the target language. In this situation, the use of the teaching techniques and the selection of functional materials that have a very important role in determining the success of the BIPA learning process. Therefore, the use of authentic materials will help students, especially for students who are not familiar with the target language (Heritaningsih, 2007).

One part that is often forgotten in the teaching BIPA is a component of Indonesian culture. BIPA students often experience a culture clash when they get 
ISLLAC

Journal of Intensive Studies on Language, Literature, Art, and Culture

Vol. 1 No. 1 September 2017

into this cultural situation. This problem can be bridged by using authentic Indonesian culture as BIPA teaching materials. Authentic materials can be taken from real events in the community, newspapers, television news footage of events in Indonesia, radio programs, menus in restaurants, advertising, and so on. Armed with these materials, BIPA students have expected awareness of Indonesian culture and can actualize themselves appropriately in the Indonesian language.

\section{THE LEARNING OBJECTIVES OF BIPA}

The purpose of foreign students studying BIPA is to facilitate the Indonesian language and know the culture of Indonesia closely. Indonesian language fluency is required by them. The capabilities are needed by them because they (a) take on Indonesian program at their university, (b) will conduct research in Indonesia, (c) will work in Indonesia, and (d) will stay in Indonesia for a long time. An overview of the purpose of the study has implications for the preparation of BIPA learning materials. Thus, the BIPA learning materials have to be selected materials that a close connection with the objectives and needs of BIPA students.

Mackey and Mountford (in Sofyan, 1983) explained that there are three requirements that drive a person to learn the language, namely (1) the need for employment, (2) the need for vocational training programs, and (3) the need to learn. Furthermore, Hoed (1995) stated that BIPA program aims to (1) attend to learning classes in Indonesia, (2) read books and newspapers for research purposes, and (3) communicate orally in daily life day in Indonesia. The third purpose of each can still further divided into some special purpose, for example, to attend college in Indonesia Indonesian require knowledge in areas of science that followed (social sciences, engineering sciences, economics, and so on). Similarly, for the purpose of research depends on what areas to be studied, in which the research will be done, who is the subject of research, and so on. To learn the Indonesian language spoken by the population for purposes of communication is also necessary specialization, such as formal or informal communication. Based on the needs and the learning 
ISLLAC

Journal of Intensive Studies on Language, Literature, Art, and Culture

Vol. 1 No. 1 September 2017

objectives, materials BIPA selected and prepared in accordance with the requirement or relevance to the achievement of that goal.

\section{THE NORMS OF SELECTING BIPA TEACHING MATERIALS}

It is important to note that the BIPA learning objectives are to make foreign students are eager to learn Bahasa Indonesia and able to use it well in real situation and communication. The statement turned out to be interpreted in various ways by the organizers and teachers BIPA. In learning BIPA, we found that there were BIPA teachers who prefer to use a formal Indonesian language. They prefer to use appropriate Indonesian language materials that focused on language structures and apply teaching techniques in the training model of grammar. Elsewhere, BIPA teachers also found that only focuses on the use of language learning activities in real situations, regardless of the accuracy of the structure of the language it uses. Direction and orientation diversity have an impact on the choice of learning and teaching materials in the presentation of learning activities BIPA.

BIPA learning that direct foreign students to use appropriate language structures is influenced by the method of grammar. Choice of learning materials is more focused on the rules of the Indonesian language. Language variation reduction through the selection of language features is the most common and neutral to basic reference in determining the teaching materials. In determining instructional materials, BIPA teachers choose a language feature that (a) has a frequency of use and the high acceptance, (b) widely used, (c) is not too complex to be studied, and (d) gradual change towards a feature rarely used, its use is narrower, and more complex variants (Valdan in Magnan and Walz, 2002). In teaching-learning BIPA, foreign students are trained to use the features of the language through listening, speaking, reading, and writing.

Learning BIPA is focused to make foreign students able to use the language in real situations. This principle directs learning to use a model of communicative learning. In teaching-learning activity, a teacher provides an opportunity to the students to use Bahasa Indonesia as much as possible in communication. The 
ISLLAC

Journal of Intensive Studies on Language, Literature, Art, and Culture

Vol. 1 No. 1 September 2017

pedagogical norms suggest the selection and arrangement of the prioritized sequence materials of language features for the sake of learning. The data used as the language teaching materials is a data utterance native speakers in a variety of social contexts are selected based on the needs of language learners. Because of native speech data is very diverse, in the selection of teaching materials, Valdan (in Magnan and Walz, 2002) suggested that the material chosen language as the teaching materials should (a) reflect the actual speakers of the target language utterances in communicative situations authentic, (b) in accordance with the idealized language usage by native speakers, (c) in accordance with the expectations of native speakers and learners of foreign languages with respect to the type of behavior that fits the needs of foreign students, and (d) factors into account and learning process.

With regard to the second principle of learning BIPA that has been described above, to develop an ideal learning BIPA, teachers have to consider two principles proportionately. The selection of learning materials needs to pay attention to the authenticity of the data subject and communicative language so that conversations conducted by students really meaningful because it addresses the real thing, not a fictitious conversation. Thus, learning will be more easily followed and learning materials will be easily understood by students. Pedagogical norms of language learning activities need to emphasize the meaning, function, and context.

In building conducive classroom activities, it is necessary to create effective communication between students and teachers. Effective communication can be done if the selected learning material completely functional for students. Eskey (1986) explained that the students who the lower ability need the target language learning materials that emphasize to the identification form, whereas the target language learners who require high skills of learning materials that emphasize to the interpretation of meaning. For the first group of students who normally reside in the beginner class, which emphasizes the use of authentic materials that is a very important aspect because it serves to bridge the communication gap between students and teachers. With proper use authentic materials, students will be able to 
ISLLAC

Journal of Intensive Studies on Language, Literature, Art, and Culture

Vol. 1 No. 1 September 2017

follow the learning by utilizing basic knowledge to guess the teaching material learned.

In the early stages, learning BIPA directed to encourage foreign students willing and able to express ideas, feelings, and opinions with the Indonesian language. To that end, the teaching materials used may be real events that can be observed by the learner, visual impressions, or text with a topic that is "now" and "here" that can be understood by the learner. In this case, the precision of language structure and grammar error correction priority has not been a priority of learning. Therefore, in the choice of language data in the form of specified materials wherever possible the correct language of the rules of the language. At a later stage, when the students have started to emerge their willingness and ability to develop language, the correct use of language and grammar error corrections start to become the focus of attention. However, the error correction undergo structural language learners, teachers need to consider (a) the effect on the error message, (b) if the error rate is measured by the error rate experienced by native speakers, and (c) the relationship between the fault and the system state of the language learner.

\section{THE VARIETIES OF BIPA TEACHING MATERIALS}

In the learning BIPA, learning targets are emphasized to four aspects of learning language skills, namely listening skills, reading skills, speaking skills, and writing skills. Listening and reading are receptive proficiency, speaking and writing are productive proficiency. The ideal language acquisition includes the four types of proficiency. However, in reality, there are a BIPA students fluent in speaking Bahasa Indonesia, but they are a weakness in reading or writing. Conversely, there are students who are able to read the text and write the contents of text correctly, but many have difficulty in conveying his opinion orally (Lado, 1985). To solve this problem, BIPA learning needs to develop exercising for four aspects of such proficiency in proportion to the needs of their students.

In learning BIPA to develop the proficiency of listening and speaking skills, the material can be used in the form of dialogue. Material intended dialogue can be 
ISLLAC

Journal of Intensive Studies on Language, Literature, Art, and Culture

Vol. 1 No. 1 September 2017

either text conversation developed by BIPA teachers with an emphasis on everyday topics about real events that required language and can be applied by students in the day-to- day communication. Learning materials in the form of text dialogue are very useful to improve and enrich the vocabulary of foreign students. Instructional materials that use this dialog can be started from a very simple dialog, for example, dialogue about greetings in Indonesian. Simple dialogue is appropriate for beginner students. For advanced students, for developing the two skills, teaching materials in form of dialog should be more complex and more formal language. Topics selected dialogue should also formal topics, such as formal conversations in the office.

To enrich the knowledge of BIPA students about greetings in Indonesian, it is needed to introduce a number of greetings that can actually be found in everyday personal communication. Therefore, the material further dialogue can be developed with a variety of other forms of expression of greeting and the forms need to be trained to BIPA students well. The examples of enrichment materials about various expressions of greetings are selamat pagi, selamat siang, selamat sore, selamat malam, selamat jalan, selamat makan, etc. To determine whether students have grasped the material dialog correctly or not, their achievement needs to be checked through the exercising of understanding the content of the dialogue.

Teaching techniques used by a teacher to accelerate students in learning complex dialog is a modeling. In this case, the teacher read the text and students listen while marking new words that have not understood the meaning. After reading the dialogue is completed, the teacher provides the opportunity for students to find new difficult words in the text dialog. New words in question by BIPA students discussed with the class. Wherever possible teachers in explaining the meaning of new words in a way that does not translate into the language learner, but it can be done through the interpretation of the meaning based on context or explain by giving illustrations. To check student understanding of new words, the teacher asks students to make sentences with the words. After all the new words in the text dialog understood by students, BIPA teachers provide a training to students in pairs to read 
ISLLAC

Journal of Intensive Studies on Language, Literature, Art, and Culture

Vol. 1 No. 1 September 2017

the dialogue. If the text is considered too long, teachers can divide the text into sections.

The training forms of the dialog can be followed by assignments for students to change the statement, answer, or phrase in the text dialog with the form of statements, answers, or other expressions according to the context and the student wishes. It is important for students because in real communication students will encounter various forms of statements, answers, or the expression. Introduced with the various forms of the learning experience, the gap between the use of Bahasa Indonesia in class and in the real communication can be addressed.

With reference to the text, the dialog has been learned, classroom activities can proceed with his training to respond spontaneously to any form of inquiry. To activate and bring creativity students, teachers ask students to close the book material. The question is not only initiated by teachers, but also each student is assigned to ask and answer questions so that students are more active and more varied learning activities.

To improve students' ability in communication, classroom activities can be done with his training development of creativity. Students creatively make statements or questions submitted to his/her friends, then his/her friends to respond to the statements or questions. This can be done in pairs so that students are able to create interactive communication with their partner.

Learning BIPA with the dialogue model can be done by presenting the topics dialogue, without the use of dialogue that has been composed before. Topics such dialogue can be determined by the teacher or students based on mutual agreement. In learning activities, teachers and students discuss mutually convey thoughts and opinions from the perspective of each of the topics that have been agreed. Choice of presentation material in a way so is the potential to explore and develop student competence in the language. Because of the choice of topics based on student choice in accordance with their interests, students have the supplies and wealth ideas that can be communicated to another. In these conditions, it is possible students having difficulty to find the words to convey his thoughts Indonesian. Students then bring 
ISLLAC

Journal of Intensive Studies on Language, Literature, Art, and Culture

Vol. 1 No. 1 September 2017

his ideas into English. At that moment, the teacher should help the student to demonstrate the Indonesian language.

To start a dialogue with this model of learning, teachers first give an overview of the topics to be discussed or talked about. Submission of these images can be done through the story, the events in the video, pictures, and so on. If the topic comes from learners, initial overview of the subject can be submitted by the student concerned. After an overview of the subject possessed by all students in a class, a dialogue on the topic can be started.

In this learning activity, the content of any comments, answers, opinions, and comments are not assessed student right or wrong, or not considered good and bad, because the problem is not the focus of attention in learning. Most important in this activity, students willing and able to express their opinions by using the appropriate Indonesian. Therefore, the focus of attention is the language used by students instead of talking about the quality of content material. In addition to the material in the form of dialogue, in teaching listening and speaking, is accomplished by utilizing the material in the form of discourse that exists in everyday speaking activities, such as news or conversations on television, radio, and a crowd of people in everyday life.

Learning to listen to the news or conversations in utilizing electronic media can be done in two ways, namely (1) teachers and students together in a classroom listening activity or conversation then discuss the news and asking for feedback from the students about what they listen, or (2) teacher assigns students individually or in groups to listen to the news or conversations outside the classroom activities and then on the next day of class activity students were asked to report information and responses about what their listen. While learning to listen to conversations that take advantage of the crowd of people can be done in the activity of individual tutorials. Individual students are accompanied by a tutor in a crowd of people who were talking and listening to the information being discussed by them. Obtained information presented in the class at the next meeting.

Various materials of dialogue as described above, in terms of complexity and grain, need to be adjusted to the conditions and the ability of the students. For the 
ISLLAC

Journal of Intensive Studies on Language, Literature, Art, and Culture

Vol. 1 No. 1 September 2017

beginner level, the materials should be chosen for the material dialog with simple everyday topics in Indonesian. The material chosen for the mid-level dialogue rather complex everyday and formal dialogues are simple. Meanwhile, for a given level of advanced materials is more complex dialog better deals with daily topics and formal topic.

Development of reading and writing materials is tailored to the ability level of their students. For the beginner level given readings in simple Indonesian, given to mid-level readings in Indonesian is rather complex, and for advanced reading, Indonesian awarded more complex. Simple reading materials can be developed by teachers or obtained from the existing literature on children's magazines or reading a book is in Indonesian at primary school, but have chosen a topic of interest and in accordance with the interests of adult learners.

For the intermediate and advanced student, learning to read can take advantage of reading in newspapers or magazines. Reading materials provided to the learner are a high complexity in the material language. The complexity of the language in the text is almost the same with the complexity of a real language used by native speakers of Indonesian. However, to maintain the meaningfulness and learnable by students, selected reading materials should remain tailored to the interests and abilities of students.

Advanced students generally already have awareness of learning and independent learning. Prior learning in the classroom, they usually have to prepare by studying the learning materials that have been scheduled. Therefore, the teacher must really prepare teaching materials as well as possible so that the students ' learning motivation is maintained. In learning to read, when the teacher gives reading material which is difficult because of a lot of new words, teachers need to provide a list of difficult words and its translation at the end of the reading. It is intended to facilitate students in understanding the content of the text and to avoid the onset of saturation because students face a lot of difficulty understanding.

The exercise of reading comprehension can be developed through a variety of models. The models are (1) answering reading questions, (2) completing the blank 
ISLLAC

Journal of Intensive Studies on Language, Literature, Art, and Culture

Vol. 1 No. 1 September 2017

sections of text reading, (3) revealing the contents of the reading, (4) summarizing the content of reading by using their own language, (5) making conclusions reading the contents of and (6) commenting the content of reading. The forms can be made in his training varied as students at advanced levels deemed capable of processing and operating system that has mastered the language as appropriate.

There is still one aspect of language skills that need to be mentioned again in this paper, namely writing skills. Teaching writing skills can be forms of writing sentences, writing a simple essay, writing a paper for a seminar in the seminar in its class. When the teacher gives his training in teaching reading and students answer questions or write answers in writing about the content of reading assignments, actually students have gained a training to write. For example, when students disclose the contents of paragraphs and write conclusions of the reading text, students' activities and practices are learning to write. In the learning BIPA, students sometimes are assigned to write an essay. In this case, students were assigned to compose a simple report or papers.

In an effort to develop the learner's ability to use language correctly and acceptable, learning grammar was still needed. The grammar learning is intended to equip BIPA students well aware about the use of the structure of the true Indonesian. The learning provides many significant benefits for the improvement of language learners as well as provides supplies and services to the students in understanding the text in scientific books in the Indonesian language.

Selection of language in the learning material is tailored to the language ability of BIPA students. BIPA language material for beginner level students include greeting words, simple everyday phrases, simple sentences, active sentences, passive sentences, negative sentences, prepositions, word/sentence asked, said numbers, and simple affixation. BIPA language materials for intermediate level learners include the following phrase in Indonesian, complex sentences, active sentences, passive sentences, negative sentences, transitive and intransitive sentences, prepositions, interrogative sentence, and more complex affixation. Meanwhile, for advanced students, the language materials are substantially similar to the material for the 
ISLLAC

Journal of Intensive Studies on Language, Literature, Art, and Culture

Vol. 1 No. 1 September 2017

intermediate level. The differences are in the levels of complexity. At the advanced level, the emphasis is more on the analytical understanding of the language material. BIPA students provided the ability and accuracy of language through analysis sentence wrong and correct it and change the pattern of the sentence without changing its meaning.

Developing and organizing the materials need to be tailored to the needs of their students and ability levels. Therefore, management of BIPA learning materials need to pay attention to three things, namely (1) the orientation of the material should be directed and focused on material that (a) can be used and potentially can be trained, (b) actually exists and is used in real communication society, and (c) able to develop competence to practice and understand the patterns and be able to develop an understanding of Indonesian through forms of conversation/dialogue situational-contextual, (2) the range and the arrangement of the material sought in the material that refers to those aspects that determine how Indonesian is used, the following aspects: (a) vocabulary, (b) sentence pattern, (c) discourse / conversation, (d) spelling / pronunciation and intonation, and (e) processing ideas, and (3) learning material should be arranged by units in an integrated communicative utterances (Suyitno, 2005).

In learning BIPA, students were introduced to Indonesian culture. The development of the culture material is directed to enrichment insight Indonesian culture to foreign students so they can use it as a provision within the daily life of Indonesian society. Principles of cultural materials that need to be introduced to students BIPA is a cultural behavior, cultural knowledge, and cultural objects. The principles of culture material are to equip students to be able to speak Indonesian BIPA according to the circumstances. In addition, also introduce Indonesian culture to BIPA students so as to foster a positive attitude of BIPA students about Indonesian culture (Suyitno, 2017).

Culture is all kinds of human activity and the results are patterned (Sadtono, 2002:16). In line with these opinions, cultures can be grouped into two major increments, ie, as a product of culture and culture as a whole way of life. As a 
ISLLAC

Journal of Intensive Studies on Language, Literature, Art, and Culture

Vol. 1 No. 1 September 2017

product, including intangible cultural values, beliefs, norms, symbols, and ideology, while as a way of life, a culture of human relations and human attitudes or behavior in a relationship with one another (Thompson, 1990:1).

\section{TEACHING-LEARNING TECHNIQUES}

In relation to the BIPA learning techniques, there are a few things to note, that are (1) How to the delivery of materials to the students, (2) how to face students, and (3) how to create a learning atmosphere. Techniques of learning presentation are divided into 3 phases, namely opening the lessons, presenting new materials, and closing the lessons.

There are several techniques that can be done in starting teacher in class, among which are (1) greetings (greetings), (2) asking the state/situation at a residence, (3) asking his feelings, (4) asking its activities, (5) asking about the time (sleep, dream, get up, go to school, etc.), (6) telling what he/she has done (teacher), (7) asking to use words or phrases that have been given the day before, (8) asking something that was taken or that of the student, (9) responding to statements/questions from the beginning delivered learner, (10) explaining what things will be done that day or the next (Suyitno, 2004: 36).

The technique is widely used in starting teacher in class. The technique aims to create an intimate and warm atmosphere before starting the lesson. Moreover, such techniques can be used to train and encourage students to communicate using Indonesian language studies. Thus, the teacher can know how many words that have been mastered by the student, the problem is he/she having trouble, what things need to be repeated. Another advantage that can be gained from the start lesson technique in this way is the teacher can provide the additional words that fit the needs of the current students, and the words so this is actually functional for students. This is in accordance with the opinion of Richard and Rodgers (1983) who explained that (1) learning occurs when it takes place in a real communication, (2) the communication activities like this, obviously the language is used, and (3) the use of this is a real language for meaningful student or functional. 
ISLLAC

Journal of Intensive Studies on Language, Literature, Art, and Culture

Vol. 1 No. 1 September 2017

In learning BIPA, some teachers also use total immersion technique. Various ways are used for the presentation of the material of which is how to frequently asked questions, training, assignments, demonstrations, providing both group and individual consultations, tutorials, drill, and correction. In the presentation of new material, the way that can be done by the following activities.

1) The material in the form of dialogue : (a) teachers read the dialogue then students mimicked (this way, especially for beginners, to intermediate and advanced level teachers, do not need to give an example), (b) teachers refer students to read the text of the dialogue, (c) teachers give example how to pronounce words correctly, (d) teachers assign the students in pairs to act out what is in the text dialog, (e) teachers ask students to close the book and then respond to questions/statements are taken from the text teacher dialogue, (f) teachers assign students to engage in dialogue with the free use of words according to the topics in the text dialog newly learned, (g) teachers give students a chance to ask the difficult words in the text dialog, (h) teachers ask students to make sentences with the new words in the dialogue, and (i) teachers assign students to do the exercises either orally or in writing.

2) The material is in the form of reading : (a) teachers express initial explanation about the content of reading (pre-reading), (b) teachers ask and answer with students about things that exist in the literature, (c) teachers ask students to read readings per paragraphs, and check their understanding of the content, (d) teachers ask students to find difficult words, and (e) teachers assign students to do the exercises and questions about the content of reading.

3) The material is in the form of grammar: a grammatical material presented in the form of exercises. Therefore, students are trained to answer direct questions and grammar exercises. The teacher explains the grammar when students have difficulty in doing the task and answer the exercises. The explanation given by the teacher is not an explanation in terms of the language of science, but an explanation of how it should be said or structure is used in the language. 
ISLLAC

Journal of Intensive Studies on Language, Literature, Art, and Culture

Vol. 1 No. 1 September 2017

In the implementation of immersion techniques, teachers do not use the English language to the students. Students are recommended to use the Indonesian language. If they were once given the chance to speak English, they will always ask for an explanation in English. This is consistent with the statement Wolff, et al. (1988) who suggested that BIPA teachers need to consider the following techniques in the teaching of BIPA, namely (1) speak to the students in Indonesian, (2) use words, formations, sentences, and grammar are already known to students, (3) do not provide the opportunity and flexibility to the students to speak English, even if they have not been able to convey meaning with good Indonesian, (4) speak naturally, (5) when the students say the sentence is one sentence that is meant to say, well, then take them to repeat it, (6) the mistakes made by students shall be addressed as a collective error, (7) an explanation of the words or terms should be based on aspects socio-semantic with effective use of examples, and (8) if students have difficulty in training (speech and arrest) sentences long, cut the sentence in a meaningful units ranging from the end of the sentence.

Learning BIPA is not only done in the classroom but also done outside the classroom. Techniques adopted in the presentation of the material through activities outside the classroom through activities including outdoor tasks (to the bank, to the photo studio, to the market), visiting, interviews with Indonesian students, visits to tourist places, see things craft (puppets, ceramics, masks), see performances, witnessed ceremonies (weddings, funerals), and so on. Such a way that is consistent with the opinions expressed by Surajaya (1995) who argued that the tips to do in teaching BIPA is (1) college tips, (2) issue an explanation with examples of cultural objects, (3) demonstration and participation tips active, (4) tips field visit or excursion, (5) tips magazine wall, (6) tips dancing and singing, (7) tips game simulation, (8) native informant tips, (9) tips video - tape, (10) tips audio -motor units, (11) tips culturally Identification of general behavior, (12) tips the identification of cultural connotations, (13) tips minimization of perception that is stereotyping, and (14) tips utilize authentic literature. 
ISLLAC

Journal of Intensive Studies on Language, Literature, Art, and Culture

Vol. 1 No. 1 September 2017

In language learning in the classroom, the classroom atmosphere will determine the success of learning. Classes are necessary to create a good atmosphere in learning. There are several ways that can be done by BIPA teachers in creating a classroom atmosphere so that teaching and learning take place, namely (1) the use of humor, (2) change/provide challenging materials, (3) give the song, (4) providing puzzles (puzzles), (5) provide to students to take a break, and (6) encourage students to move to another place, for example (outside the classroom, in a coffee shop, etc. (Suyitno, 2005).

In addition to the presentation of material engineering, engineering students face both in the classroom and outside the classroom requires attention in learning BIPA. It is given that the student is not a student BIPA Indonesia, namely foreign students who have different cultural backgrounds with the instructor. Some techniques that can be taken in addressing the BIPA students both inside and outside the classroom are (1) shows the attitude of discipline with respect to time, (2) demonstrate responsible attitude towards work/assignments, (3) shows the attitude as a friend, (4) shows attitude that knows the language problems, (5) shows the attitude of patient and painstaking, (6) shows an open attitude, (7) shows the lackluster attitude.

\section{CONCLUSION}

Learning BIPA has significance for the development and promotion of Indonesian culture for the people of Indonesia. Through learning BIPA, foreigners will be easier in knowing and studying Indonesian culture. Therefore, BIPA learning needs to prepare materials and learning techniques that can meet the learning needs of foreign students. Therefore, BIPA teachers need to understand correctly the pedagogical norm of BIPA learning.

Foreign students studying BIPA aim to be able to use the Indonesian language. Mastery of the Indonesian language is intended by foreign students for various purposes, both academic and non-academic purposes. Therefore, BIPA 
ISLLAC

Journal of Intensive Studies on Language, Literature, Art, and Culture

Vol. 1 No. 1 September 2017

learning materials chosen to be taught to BIPA students are potential materials to meet their needs. These materials include language and grammar skills.

In the learning process, BIPA teachers need to use a variety of techniques. It is intended to serve BIPA students who have varied cultural background and language skills. Therefore, BIPA teachers should really have and master the various tricks that can encourage BIPA students to enjoy and be able to learn the Indonesian language.

\section{REFERENCES}

Ellis, R. (1986). Understanding Second Language Acquisition. Oxford: Oxford University Press.

Gass, S.M., et.al. (eds.). (2002). Pedagogical Norms for Second and Foreign Language Learning and Teaching. Philadelphia: John Benjamins Publishing Company.

Heritaningsih,A. (2007). Pengembangan Bahan Ajar BIPA Melalui Materi Otentik yang Bermuatan Budaya Indonesia. Retrieved form http://www.pusatbahasa.diknas.go.id/ laman/nawala.php?info $=$ artikel\&infocmd $=$ show\&infoid $=61$ \&row $=3$.

Hoed, B. H. (1995). Kerjasama Antarpemerintab dan Antarlembaga untuk Pengembangan BIPA. Paper of BIPA Conference 1995, Faculty of Letters, Indonesia University Jakarta.

Magnan, S. S. \& Walz, J. (2002). Pedagogical Norms: Development of Concept and Illustrations from French, in Gass, Susan M, et.al (eds.). 2002. Pedagogical Norms for Second and Foreign Language Learning and Teaching. Philadelphia: John Benjamins Publishing Company.

Richards, J.C. \& Rogers, T.S. (1983). Approaches and Methods in Language Teaching. Cambridge: Cambridge University Press.

Sadtono, E. (2002). Perlukah Kita Memahami Kebudayaan Asing? Paper presented in Kursus Pramuwisata Muda Jatim at Surabaya Oktober, 7-11 2002.

Sofyan, L.A.S. (1983). Pengajaran ESP pada Tingkat Perguruan Tinggi, in Linguistik Indonesia, thn. I No. 1, Januari 1983.

Sugino, S. (1995). Pendekatan Komunikatif-Integratif-Tematis dalam Pengembangan Baban dan Metodologi Pengajaran BIPA di Indonesia, Paper of Kongres BIPA 1995 Fakultas Sastra Universitas Indonesia Jakarta. 
ISLLAC

Journal of Intensive Studies on Language, Literature, Art, and Culture

Vol. 1 No. 1 September 2017

Suyitno. I. (2017). Reconstruction of Basic Knowledge on Learning BIPA for Developing Professionalism of BIPA Teachers, IJRDO-Journal of Educational Research, Volume-2, Issue-2, February 2017, retrieved from ww.ijrdo.org/...Development.../ Educational\%20Research-February-201717.pdf

Suyitno, I. (2005). Bahasa Indonesia untuk Penutur Asing: Teori, Strategi, dan Aplikasi Pembelajarannya. Yogyakarta: CV Grafika Indah.

Suyitno, I.. (2004). Pengetahuan Dasar BIPA: Pandangan Teoritis Belajar Bahasa. Yogyakarta: CV Grafika Indah.

Thompson, M., Ellis, R. \& Wildavsky, A. (1990). Cultural Theory. Oxford: Westview Press.

Wojowasito, S. (1976). Perkembangan Ilmu Bahasa (Linguistik) Abad 20. Bandung: Shinta Dharma.

Wolff, J.U., Oetomo, D., \& Fietkiwicz. (1988). Beginning Indonesian Through SelfInstruction, Book 1. Ithaca: Cornell University, SEAP. 